\title{
INSURANCE AGAINST TORT LIABILITY-AN APPROACH TO THE COSMOLOGY OF THE LAW
}

\author{
George K. GardneR*
}

Insurance against tort liability has now become an everyday incident of American life. Many would not think of driving a car, owning a building, or carrying on a business without it; the law requires a great many people to carry it as a condition of their daily activities; it is probable that insurance companies pay more than half of all the tort judgments which are rendered each year. The business of writing such insurance is not a new one. It has been practiced for more than half a century; its routines are familiar to thousands whose livelihood it supplies. Nothwithstanding all this, the law of the subject is riddled with absurdities and unsolved problems; there exists no authoritative legal treatise about it in this country; ${ }^{1}$ there is no casebook designed to assist its study; and the treatment of the subject in the existing casebooks on general insurance law is fragmentary and incidental to their main plan. This is an arresting, a challenging, state of affairs. It asks the law professors where they have been all this time. It at least suggests the hypothesis that a system of legal doctrine and legal instruction which neglects a fact at once so obvious and so pervasive has lost its touch with the times.

A little reflection will, I think, make it apparent how this situation has come to pass. Throughout the whole of the half century during which liability insurance has been evolving in practice the orthodox law curriculum has been starting novices on their studies with the proposition that the civil responsibility of the citizen is divided between Contract and Tort. This proposition-like the proposition that all Gaul is divided into three parts-is not easy to get out of one's head. It has been reinforced by the enormous prestige of the American Law Institute, which has propounded six hundred and nine black letter sections about Contracts and nine hundred and fifty-one black letter sections about Torts as the authoritative restatement of the American law. Now if you believe that the whole law of civil responsibility is divided into Contract and Tort, the subject of liability insurance at once becomes very recondite and abstruse. That it involves both of the two kinds of civil responsibility is, of course, obvious at a glance. If the glance pauses and becomes reflective, it begins to look as if it involved both rather deeply; that perhaps it not only crosses the boundary between Contract and Tort but erases it; that maybe to really understand insurance against tort liability you must think Contract and

- A.B. 1912, LL.B. I9r4, Harvard University. Member of the Massachusetts bar. Professor of Law, Harvard University, since 1928 .

1 But many of the questions raised in this paper are systematically treated in an English treatise: C. N. Shawcross, The Law of Motor Insuranice (1935). 
Tort through again. This, of course, is rather too much for the busy practitioner or the harassed law school instructor to do. What was the use of going to law school if you can no longer rely on the basic truths you learned the first year? That, perhaps, is why it falls to the lot of one who has pretty well used up his stock of acquired dogmas and must, perforce, go to school again, to open up a train of thought which perhaps other men may pursue.

The distinction between Contract and Tort may possibly not be of the essence. It is conceivable that we might forget all about it and still preserve private enterprise, the dignity of the individual, the administration of impartial justice, and the American way of life. At any rate, one may safely suggest this possibility in I950 without risking a charge of subversion, now that the distinction has been abolished for eleven years in the federal courts. The Federal Rules of Civil Procedure, adopted on September 16,1938 , permit every kind of civil responsibility to be enforced in one form of procedure known as a "civil action." If civil responsibility may be viewed as a unit for purposes of procedure, it is at least possible that it may be viewed as a unit from the standpoint of substantive law.

\section{Liabiuity Insurance and Contract}

Suppose we begin by examining the essential provisions of the automobile liability insurance contract now in common use. The following extracts are taken from the sample policy which Professor Edwin W. Patterson has selected for the appendix to his excellent casebook on insurance law. ${ }^{3}$

$\mathrm{X}$ Casualty Insurance Company agrees with the insured, named in the declarations made a part hereof, in consideration of the payment of the premium and in reliance upon the statements in the declarations and subject to the limits of liability, exclusions, conditions and other terms of this policy....

Coverage A

Bodily Injury Liability: To pay on behalf of the insured all sums which the insured shall become obligated to pay by reason of the liability imposed upon him by law for damages, including damages for care and loss of services, because of bodily injury, including death at any time resulting therefrom, sustained by any person or persons, caused by accident and arising out of the ownership, maintenance or use of the automobile.

\section{Coverage B}

Property Damage Liability: To pay on behalf of the insured all sums which the insured shall become obligated to pay by reason of the liability imposed upon him by law for damages because of injury to or destruction of property, including the loss of use thereof, caused by accident and arising out of the ownership, maintenance or use of the automobile.

Defense, Settlement, Supplementary Payments: As respects such insurance as is afforded by the other terms of this policy

${ }^{2}$ FED. R. Crv. P. 2.

a Edwa W. Patterson, Cases and Materiars on the Law of Insurance 783-801 (2d ed. 1947). 
(a) under coverages $A$ and $B$ the company shall

(I) defend in his name and behalf any suit against the insured alleging such injury or destruction and seeking damages on account thereof, even if such suit is groundless, false or fraudulent; but the company shall have the right to make such investigation, negotiation and settlement of any claim or suit as it may be deemed expedient by the company. . . .

Definition of "Insured." The unqualified word "insured" wherever used in coverages $A$ and $B$ and in other parts of this policy, when applicable to such coverages, includes the named insured and, except where specifically stated to the contrary, also includes any person while using the automobile and any person or organization legally responsible for the use thereof, provided the actual use of the automobile is with the permission of the named insured. ...

Name of Insured: (John Smith)

Limit of Liability for Bodily Injury Liability: $\$ 10,000$ each person; $\$ 20,000$ each accident.

This now commonplace form-which would certainly be described as a contract and which is probably enforceable according to its terms anywhere in the United States of America-raises at least three problems in the law of Contracts which are not as clearly answered by the Contracts Restatement as they are in practice, and which suggest that Chapter 6 of the Restatement might not unprofitably be revised. These problems involve the application of sections $133,134,139,142,143$, 147, and 572 of the Contracts Restatement which are quoted below. ${ }^{4}$

\footnotetext{
"Restatement, Contracts (1932). \$133. Definition of Donee Beneficiary, Creditor Beneficiary, Incidental Beneficiary.
}

(I) Where performance of a promise in a contract will benefit a person other than the promisce, that person is, except as stated in Subsection (3):

(a) a donee beneficiary if it appears from the terms of the promise in view of the accompanying circumstances that the purpose of the promisee in obtaining the promise of all or part of the performance thereof is to make a gift to the beneficiary or to confer upon him a right against the promisor to some performance neither due nor supposed or asserted to be due from the promisee to the beneficiary;

(b) a creditor beneficiary if no purpose to make a gift appears from the terms of the promise in view of the accompanying circumstances and performance of the promise will satisfy an actual or supposed or asserted duty of the promisee to the beneficiary, or a right of the beneficiary against the promisee which has been barred by the Statute of Limitations or by a discharge in bankruptey; or which is unenforceable because of the Statute of Frauds; (c) an incidental beneficiary if neither the facts stated in Clause (a) nor those stated in Clause (b) exist.

(2) Such a promise as is described in Subsection (ra) is a gift promise. Such a promise as is described in Subsection ( $r b$ ) is a promise to discharge the promisee's duty.

(3) Where it appears from the terms of the promise in view of the accompanying circumstances that the purpose of the promisee is to benefit a beneficiary under a trust and the promise is to render performance to the trustee, the trustee, and not the beneficiary under the trust, is a beneficiary within the meaning of this Section.

$\$ 134$. Contracts to Which Statements in This Chapter Arc Applicable. The statements in $\$ \$ 135-$ 147 are applicable both to absolute and conditional promises in either formal or informal contracts. 5139. Beneficiaries Unidentified at the Time of Contract. It is not essential to the creation of a right in a donee beneficiary or in a creditor beneficiary that he be identified when a contract containing the promise is made.

5142. Variations of the Duty to a Donee Beneficiary by Agreentent of Promisor and Promisec. 
The first problem relates to the rights which accrue under the policy to anyone who may suffer personal injuries as a result of the operation of John Smith's car. Apparently such a person is a creditor beneficiary under Section r33, and Section I43 presumably applies. But may John Smith, if amply solvent, release X Casualty Company from all obligations under the policy while the claim of the injured person remains unpaid? Section 143 does not answer that question explicitly. It would seem possible to argue it persuasively either way. In many states the question could hardly be argued without reference to statutes. Here, at any rate, is a basic question with which a treatise on liability insurance would have to deal.

The second interesting question is: What kind of a beneficiary is the person who is "insured" under the policy because he drives John Smith's car with John Smith's consent? He cannot be an "incidental beneficiary" because then the policy would not protect him, as it doubtless does. He does not answer the description of a "creditor beneficiary"; so he must be a "donee beneficiary," which he doubtless is. But if so, do Sections 139 and I 42 make X Casualty Company responsible to one to whom John Smith lends his car during the original term of the policy but after the policy has been cancelled by agreement between X Casualty Company and John Smith? It seems scarcely possible that this question could be answered in the affirmative, but Sections I 39 and 142 seem easily capable of interpretation either way.

A third question, which cuts more deeply than the last two, is: How can an insurance contract such as that which has just been quoted be legally valid at all? It can hardly be thought that the law would enforce A's promise to indemnify B against liability for a contemplated assault and battery. How can it be that the law will permit John Smith to contract to shift onto other shoulders a tort liability which has been "imposed upon" John Smith "by law"? The American Law Institute's answer to this question is expressed in Section 572 of the Contracts Restatement, but it is submitted that that answer is not complete. How can it be asserted with any confidence that the contract does not "tend to induce" accidents caused by the negligent driving of the car? Certainly there must be many drivers who, if they

Unless the power to do so is reserved, the duty of the promisor to the donee beneficiary cannot be released by the promisee or affected by any agreement between the promisee and the promisor, but if the promisee receives consideration for an attempted release or discharge of the promisor's duty, the donee beneficiary can assert a right to the consideration so received, and on doing so loses his right against the promisor.

\$143. Variation of the Promisor's Duty to a Creditor Beneficiary by Agreement of Promisor and

Promisee. A discharge of the promisor by the promisec in a contract or a variation thercof by them is effective against a creditor beneficiary if,

(a) the creditor beneficiary does not bring suit upon the promise or otherwise materially change his position in reliance thereon before he knows of the discharge or variation, and

(b) the promisec's action is not a fraud on creditors.

\$r47. Effect of a Promise of Incidental Benefit. An incidental beneficiary acquires by virtue of the promise no right against the promisor or the promisee.

\$572. Bargain to Indemnify Against Consequences of Committing a Tort. A bargain to indemnify another against the consequences of committing a tortious act is illegal unless the performance of the tortious act is only an undesired possibility in the performance of the bargain, and the bargain does not tend to induce the act. 
could not have insurance, would either drive more cautiously or not drive at all. If it be answered that a confident and unworried driver is normally safer than an anxious and frightened one, are we to interpret the Restatement as meaning that the effect of this particular policy on John Smith's personal psychology at the time of the accident is triable whenever an action against $\mathrm{X}$ Casualty Company upon the policy is brought? It hardly seems possible that that is the law. I submit, with deference, that section 572 of the Contracts Restatement is an inadequate statement of the doctrine which underlies the unquestioned validity of the insurance against tort liability, and that the true ground of its validity must be found in a re-examination of the foundation principles of the law of torts.

II

\section{Liability Insurance and ToRT}

Let us now consider the legal consequences of some doings which might have resulted in litigation but which, so far as I know, never did. I did not witness these doings, but am reliably informed and believe that they occurred. Whether they occurred or not, they are perfectly possible and suffice to illustrate the problem to which I wish to call attention.

The Delaware, Lackawanna \& Western Railroad starts on the west bank of the Hudson River in Hoboken opposite New York City, pierces the cliffs of the palisades by a tunnel, and crosses the New Jersey meadows to the New Jersey hills. In the hills, along the line of the railroad, are the towns of Orange, Montclair, and other places favored by suburbanites who work in New York. It results that the commutation traffic which crosses the Jersey meadows by this railroad is very large. On its way over the meadows the railroad meets the Passaic River which it crosses, or did cross, by a drawbridge. The waters of the Passaic River at this point are navigable, tidal, and accessible by water from New York harbor by passing around Jersey City and the south end of the palisades. The Delaware, Lackawanna \& Western Railroad maintains, or did maintain, a number of powerful tugboats to handle freight lighters moving between points in New York harbor and its own wharves.

About three o'clock one afternoon a tug which did not belong to the railroad towed two barges up the Passaic River and approached the Lackawanna Railroad drawbridge. The draw was raised to allow the tug and its tow to pass. While passing through the draw, one of the barges grounded between the bridge piers. The barge was rigged with two masts which prevented the draw from being closed. The draw tender telephoned to the Lackawanna's division superintendent, who presently appeared on the scene along with a Lackwanna Railroad tug. This tug, under the division superintendent's orders, attempted to pull the barge out of the draw, but without success. The superintendent then requested permission of the barge captain to attach the tug's hawser to the top of the barge's masts and break them off. Per- 
mission to do this was refused. The division superintendent and the tug's crew thereupon overpowered the barge crew and proceeded to execute their plan by force. The barge's masts were pulled down by the tug's hawser, and the evening commuters to Montclair and the Oranges came home on time.

Was there a tort committed? And if so, who is to pay? There will be found in the footnotes a number of sections taken from the Restatements of Torts ${ }^{5}$ and Agency, ${ }^{6}$ and the learned reader may exercise his ingenuity in determining what

${ }^{5}$ Restatement, Tonts (1934). \$218. Liability to the Person in Possession. One who without a consensual or other privilege to do so, uses or otherwise intentionally intermeddles with a chattel which is in the possession of another is liable for a trespass to such person if, but only if,

(a) the chattel is impaired as to its condition, quality or value, or

(b) the possessor is deprived of the use of the chattel for a substantial time, or

(c) bodily harm is thereby caused to the possessor or harm is caused to some person or thing

in which the possessor has a legally protected interest.

5262. Privilege Created by Public Necessity. One is privileged to use or otherwise intentionally intermeddle with a chattel in the possession of another when such intermeddling is or is reasonably believed to be necessary for the purpose of averting a public disaster.

$\$ 264$. Abatement of Private Nuisance. One is privileged intentionally to intermeddle with chattels in the possession of another for the purpose of abating a private nuisance created or maintained by the possessor if such intermeddling is a reasonable means of abating the nuisance and if the possessor of the chattel, upon demand, has failed to abate the nuisance or the actor reasonably believes that such demand is impractical or useless.

\$888. Effect of Acting at Command of or on Account of Another. A person whose conduct is otherwise a tort is not relieved from liability therefor merely by the fact that his conduct is pursuant to the command of or is on account of another.

Bestatement, Agency (1933). \$343. General Rule. An agent who does an act otherwise a tort is not relieved from liability by the fact that he acted at the command of the principal or on account of the principal, except where he is exercising a privilege of the principal, or a privilege held by him for the protection of the principal's interests.

\$401. Liability in Tort for Loss Cattsed. In accordance with the principles stated in the Restatement of Torts, an agent is subject to liability for loss caused to the principal by any breach of duty except a breach of a duty arising wholly from a contract with the principal.

$\$ 438$. Indemnity of Agent: General Principles. In the absence of specific terms in the agreement of employment, the extent of the principal's duty to indemnify an agent for payments made or losses suffered by the agent in the performance of authorized transactions or as a result of such transactions is based upon a fair apportionment of the risks of the cmployment in light of business customs, the relationship of the parties, and the nature of the agent's undertaking.

5439. When Duty of Indemnity Exists. Unless otherwise agreed, the principal is subject to a duty to an agent, not barred by the illegality of his conduct, to reimburse him for or to exonerate him from:

(a) authorized payments made by the agent on behalf of the principal;

(b) payments upon contracts upon which the agent is authorized to make himself liable, and upon obligations arising from the possession or ownership of things which he is authorized to hold on account of the principal;

(c) payments of damages to third persons which he is required to make on account of the authorized performance of an act which constitutes a tort or a breach of contract;

(d) expenses of defending actions by third persons brought because of the agent's authorized conduct, such actions being unfounded but not brought in bad faith; and

(c) payments resulting in benefit to the principal, made by the agent under such conditions that it would be inequitable for indemnity not to be made.

5440. When No Duty of Indemnity. Unless otherwise agreed, the principal is not subject to a duty to indemnify an agent:

(a) for pecuniary loss or other harm, not of benefit to the principal, arising from the performance of unauthorized acts or resulting solely from the agent's negligence or other fault; or

(b) if the principal has otherwise performed his duties to the agent, for physical harm 
rights these give to the railroad company and its superintendent and what liabilities they impose on them in the situation which I have described. But it seems to me that an uninstructed judge or jury would arrive at the correct solution with less effort, and in a simpler way. "Tort" is Norman French for "wrong." Did the Lackawanna Railroad's division superintendent do wrong? He did not-his conduct was very creditable indeed. If he did not do wrong, certainly neither the railroad company nor its patrons did so. But the fact remains that the barge owner is not blameworthy and that his property has been sacrificed to the convenience of the Orange and Montclair commuters and to the preservation of the Lackawanna Railroad Company's goodwill. Since the Lackawanna Railroad Company's treasury represents both these interests, it should pay the cost of replacing the barge's masts. There is no action of any kind against the division superintendent, but there should be an action against the railroad company-and a jury, at least, is not likely to be too much troubled over how the action may be classified in the law books. The true classification, I submit, is neither tort nor contract, but debt, which, both historically and analytically, is an independent category of the law. The principle upon which the railroad company should be held liable is the same as that expressed in Section $\mathrm{I}$ of the Restatement of Restitution, ${ }^{7}$ the same as that which requires the state to make compensation for taking by eminent domain. The whole transaction is of the same essential nature as the transactions by which the railroad originally acquired its right of way.

But why, someone may ask, this extended discussion of a hypothetical and exceptional case? The answer, I submit, is that the case is not as exceptional as it seems. All the world's work is conducted under the daily pressure of necessities which demand that less compelling interests be subordinated or brushed aside. The manufacturer who must fill his orders, the bus driver who must make his schedule cannot do what they are required to do without risk of injuring someone else. The law attempts, so far as possible, to throw upon every enterprise the burden of compensating those who suffer from its pursuit. A ruling that an enterprise must pay for a particular injury which it causes is not necessarily a ruling that either the enterpriser or his servants have done wrong.

\section{III}

\section{A Reconnaissance in History}

The pertinence of what has been said will, perhaps, be more apparent if we remind ourselves of the course of history which has brought the liability insurance business into being. The spate of actions of tort which characterized the second half

caused by the performance of authorized acts, harm suffered as a result of torts, other than the tortious institution of suits, committed upon the agent by third persons because of his employment, or harm suffered by the refusal of third persons to deal with him.

${ }^{7}$ Restatement, Restitution (1936). \$1. Unjust Enrichment. A person who has been unjustly enriched at the expense of another is required to make restitution to the other. 
of the nineteenth century was not made up, in any substantial measure, of actions against individuals for their alleged personal wrongs. It was made up in the main of actions against incorporated enterprises, against cities, railroads, and manufacturing companies for alleged wrongs committed in the course of those enterprises by their employees. A good deal of speculative energy has been expended over the question why an employer admittedly guilty of no personal wrongdoing should be held responsible for wrongs committed by someone in his employ. I shall not attempt to re-examine that issue here. Instead I prefer to raise the question whether many of the accidents for which tort judgments were rendered were the result of wrongdoing, or even of anything properly described as negligence, on the part of anyone, whether there were not thousands of verdicts brought in, and sustained, against corporations where no jury would have brought in a verdict against any individual whomsoever upon the evidence presented at the bar. Certainly it was a matter of common gossip all through that era that no jury would decide a case against a "corporation" on the basis of the evidence and the law as laid down by the bench. One can scarcely doubt that the living tort law of the late nineteenth century contained a very large element of the doctrine of Rylands $v$. Fletcher, ${ }^{8}$ a doctrine that those who controlled and profited by the forces of steam, fire, and electricity, should see to it that the forces which they had set in motion paid their way.

The practice of liability insurance began with the practice of insuring "cmployers"-persons whom the law did not speak of as wrongdoers but as persons responsible for others' wrongs. The risks of tort liability in manufacturing and building were so great that the smaller enterprises would not incur them. It was to meet this demand of the smaller enterprises for protection that the business of liability insurance originated and grew up. Many of the earlier policies, unlike the modern policy which we have quoted, did not contain the underwriter's obligation to "pay" the tort obligations of the insured. On the contrary, these policies limited themselves very carefully to agreements to reimburse the insured for money actually collected from him by legal process, or voluntarily paid out. Many a recent graduate has gone through law school without being told that these policies were attacked on the ground that they purported to relieve the insured from the consequences of his own wrongdoing, and on the ground that the clause whereby the underwriter agreed to defend the insured against lawsuits was a contract to commit the tort of maintenance by intermeddling in another's cause. The charge of maintenance was not easy to answer, and was at one time sustained by the Missouri Supreme Court. ${ }^{0}$ The controversy did not cease until the general adoption of state statutes making it illegal to contract for the mere reimbursement of money paid out on tort claims, enacting that every liability insurance contract should be deemed a contract to pay whatever

\footnotetext{
${ }^{8}$ Rylands and Horrocks v. Fletcher, L. R. 3 H. L. 330 (1868).

'J. C. Breeden v. Frankfort Marine, Accident \& Plate Glass Insurance Co., 220 Mo. 327, I19 S. W. 576 (xg09).
} 
the insured was legally obligated to pay the injured party, and enacting that the obligation of the underwriter to pay the tort claim should be an asset of the insured which the injured party might reach and apply, by a process in the nature of garnishment, to the payment of his claim. The statutes were generally enacted about 19ro. ${ }^{10}$ They were substantially contemporaneous with the workmen's compensation acts generally enacted in the same decade, which required, or put pressure upon, employers to insure their employees against all accidents occurring in the "course and scope" of the employee's work.

Until about I 920 liability insurance remained characteristically insurance of employers or property owners against liability for the acts or defaults of others. It was not until the vast proliferation of automobiles during the era between the two world wars that liability insurance, by being extended to the drivers of these motor cars, came to be extended to insuring against the legal consequences of the insured's personal acts. Here again I venture the suggestion that the driver who takes out liability insurance does not think of it as protecting him against the consequences of his wrongs. He thinks of it as protecting himself and others against risks which are inseparable from the operation of a locomotive on the public ways.

\section{IV}

\section{Suggestions and Problems}

Everything that I have said about recent history is perfectly familiar to legal scholars, and everything that I have said about the present is familiar not only to lawyers but to all sorts of persons occupied with various aspects of the world's work. Why, then, should the editor permit me to use the pages of this magazine to write about it in this sketchy and fragmentary way? There is indeed no reason why he should do so except that these obvious facts seem to me to receive too little recognition in the curricula and instruction currently offered by the law schools. As I pointed out at the beginning, there is today no adequate treatise and no adequate casebook on liability insurance law. What I have tried to demonstrate is that this lack is a reflection of a profound inadequacy in the current organization of legal teaching-that it is idle to expect any systematic treatment of liability insurance by legal scholars until the whole law curriculum has been revised. Therefore, since I have not the editor's permission to use his pages for the purposes of expounding a complete Corpus Juris, the latter part of this discussion must be as fragmentary as the first. I shall content myself with pointing out a few of the practical enterprises which might be undertaken, and which ought now to be undertaken, if the opinions which I have expressed are correct.

First. It appears to me that the traditional first year law course is defective in that it plants in the student's mind the notion that the two elements of civil responsi-

\footnotetext{
${ }^{20}$ These statutes were at first attacked as invasions of constitutional freedom of contract. The United States Supreme Court did not finally sustain their validity until I925. Merchants Mutual Automobile Liability Insurance Co. v. Smart, 267 U. S. 126 (1925).
} 
bility are contract and tort. The truth, I submit, is that the elements of civil rcsponsibility are debt and trespass, and that contract, in the sense of exchange or promise, is a compound put together out of these more elementary ideas. Everyone will agree that social life would be hardly possible if individuals were free to inflict damage on one another without compensation. It is not so often recognized that the act of accepting a favor without returning it arouses almost equal resentment, that the idea of an unpaid indebtedness is anterior to, and independent of, the idea of a promise to repay. All this is abundantly demonstrated in the evolution of the law of contract through the actions of debt, covenant, and special and general assumpsit, but its importance is sometimes forgotten in the effort to modernizc everything. It is a curious and, I think, unfortunate fact that the problems ordinarily dealt with in courses and casebooks on "Quasi-Contracts" should have been assembled under so misleading a title, and that the age-old doctrines exemplified by the cases on unjust enrichment should have had so little influence on the organization of the first year curriculum as they have. It might well be a very fruitful enterprise for some teacher to examine the content of the courses on tort and contract currently offered in his law school, to imagine another first year course in "Quasi-Contracts" given out of one of the standard casebooks on that subject, and then to study the interrelationships of the three courses and how their contents might be rearranged.

Second. The elements of liability insurance law, including the law of workmen's compensation, should be included in any course which attempts to deal with the law of negligent torts. A very large fraction of all the tort judgments rendered are now paid by insurance companies, and in the absence of liability insurance would probably not be paid at all. Both plaintiffs' and defendants' counsel are, of course, well aware of this, and try to settle their cases with that in mind. It results that tort law and liability insurance law constitute in practice a single field. The student who wants "practical" instruction will approve of their being taught together in school.

Third. There is need for a thorough examination of the whole theory and practice of insurance against tort liability in the light of the doctrines of Chapter 6 of the Contracts Restatement and the public policies underlying the law of torts. The nature of the problem is well exemplified by the compulsory automobile insurance law of Massachusetts, which requires every owner of a motorcar, as a condition of registering it for travel on the public highways, to procure either (I) a "bond ... conditioned that the obligor shall within thirty days after the rendition thereof satisfy all judgments rendered against him or against any person responsible for the operation of the obligor's motor vehicle with his express or implied consent in actions to recover damages for bodily injuries, including death at any time resulting therefrom ..." or (2) "a policy of liability insurance which provides indemnity for or protection to the insured and any person responsible for the operation of the insured's motor vehicle with his express or implied consent against loss by 
reason of the liability to pay damages to others for bodily injuries, including death at any time resulting therefrom .... arising out of the ownership, operation, maintenance, control or use upon the ways of the commonwealth of such motor vehicle...."11 This statute, of course, was enacted to make sure that tort judgments against the drivers of automobiles would be paid, and the legislature apparently regarded the bond and the insurance policy as practical equivalents to that end. But it is obvious that they are not equivalents in their historical origins, that they are not equivalents in legal theory, and that they are not equivalent in their practical consequences so far as the driver of the automobile is concerned. In Massachusetts, at least, the procedures for enforcing the two instruments are quite different. Suit on the bond would be brought at law in the name of the Commonwealth for the benefit of the injured party. Suit to enforce the insurance policy would be by bill in equity to reach and apply the obligation of the policy to the payment of the judgment against the driver of the car. And there might well be differences in the substantive consequences, as we shall presently see.

Fourth. A very practical question of general national interest relates to the precise area of tort liabilty against which the ordinary automobile liability policy insures. It will be recalled that the policy quoted at the beginning of this article insures against "liability imposed ... by law for damages caused by accident and arising out of the ownership, maintenance or use of the automobile."12 Suppose John Smith, the insured under the policy, finds his running board boarded by a hitchhiker and throws him off intentionally by stepping on the gas. The hitchhiker brings an action of tort against John Smith and recovers judgment. Is this a judgment which the $\mathrm{X}$ Casualty Company must pay?

The Massachusetts court has answered this question in the negative. ${ }^{13}$ The United States Court of Appeals for the Sixth Circuit has aswered it in the affirmative. $^{14}$ From the standpoint of legal analysis the answer of the Massachusetts court seems clearly right. There is a great body of judicial decision construing policies which insure against death or injury by "accident," and it is well settled that whether a given event is "accidental" is to be determined from the standpoint of the person whom the policy insures. The hitchhiker's fall was not accidental from John Smith's standpoint, therefore, the tort liability which he incurred is not one which the $\mathrm{X}$ Casualty Company agreed to pay.

This problem, however, runs far beyond a mere question of the interpretation of the insurance contract, and raises basic questions of principle under liability insurance law. Would the Massachusetts court reach the same conclusion under a policy drawn in accordance with the statute which we have quoted? That statute requires that the policy provide "indemnity ... against loss by reason of the liability to pay

\footnotetext{
${ }^{11}$ Mass. Gen. Laws c. 90, $\$ 34$ A (r932).

12 (Italics supplied.)

${ }^{13}$ Sontag v. Galer, 279 Mass. 309, I8I N. E. 182 (1932).

26 New Amsterdam Casualty Co. v. Jones, 135 F. 2d r91 (6th Cir. 1943).
} 
damages ... arising out of the operation ... of such motor vehicle."15 These words apparently cover the present case. But, if so, do they also cover the case where the automobile is used as an instrument of intentional murder? There is, of course, no public policy against giving the injured parties a means of financial indemnity in such situations, but to hold that the driver of the car is to be "indemnified" is a novel doctrine, which seems contrary to Section 572 of the Contracts Restatement. ${ }^{11}$

Evidently we are back again to the ancient question of how far the law of torts is to be regarded as an instrument for compensating the injured, and how far it is to be regarded as an instrument for punishing the guilty. The effect of the Massachusetts statute, which seems to be to make the pursuit of these two purposes inconsistent in the present situation, was probably unintentional. Indeed, it seems likely that the real legislative policy would be expressed more exactly by a statute requiring every motorist to file a surety bond for the payment of judgments rendered against him, and leaving it optional with him whether to procure insurance against liability as well.

The present situation in Massachusetts sums up very vividly a whole chapter in the history of legal thought. When insurance against tort liability first began to be practiced it was widely held that there could be no liability in contract except in favor of a person to whom the promise sued on had been given or from whom the consideration for it moved. A fortiori there could be no liability in favor of a person not designated by the promise when it was made. It was because of this that the bonds exacted from executors, administrators, sheriffs and others to protect persons who might be injured by their defalcations were made to run in favor of designated public officers or corporations who recovered judgments thereon in trust for the persons who suffered loss. That is why the surety bond which the operator of a motor vehicle may file in Massachusetts at his election is made to run in favor of the Commonwealth. If the legislators of Massachusetts had foreseen the successive steps in the progress of the technological revolution, they would probably have enacted that no one might operate a steam engine, a gas works, or an electric dynamo without filing such a bond, and the bond, rather than the liability insurance policy, would now be the instrument normally filed by the owner of an automobile. The technological revolution would then have been accompanied by a parallel evolution of contract law. Instead of which we have now reached approximately the result which would have been reached by that route via the law of torts, the doctrine of respondeat superior, and the liability insurance policy, which seems gradually to be evolving into a combined insurance policy and surety bond.

Fifth. Another problem of general interest is the proper interpretation of the clause which defines the meaning of "the insured." In the policy which we have quoted this includes any person who uses the automobile "with the permission of the named insured." Other policies use different phrases. But whatever the phrase,

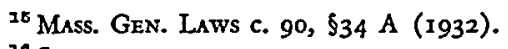

${ }^{20}$ See note 4 supra. 
there is usually room for interpretation in deciding whether the permission must be expressed or may be implied from the circumstances, and whether or not the insurance continues if the borrower keeps the car longer, takes it farther, or uses it for a purpose other than the lender of the car agreed he might.

This clause again raises the question whether insurance against tort liability should be regarded as primarily for the benefit of the tort plaintiff or the tort defendant. As the clause is drawn, it seems to be merely an accommodation extended to the servants of the named insured and to his friends who may borrow his car. But when the purchase of such a policy is made compulsory, as it is in Massachusetts, for the benefit of persons who may be injured by the operation of the car on the highways, it seems hard to see why the reason behind the statute does not require the bond or the insurance policy to cover everyone who may drive the car either with or without the owner's consent.

Sixth. Another problem which would well repay serious study is that of insurance against accidents within the family. The ancient rule, which still prevails generally, is that no action of tort for personal injuries will lie between husband and wife or between parent and minor child. ${ }^{17}$ While that doctrine prevails it is, of course obvious that a policy which insures against "liability imposed ... by law for damages" does not apply to the case of a man who injures his own wife and children. $^{18}$ In recent years the doctrine that there is no tort liability in such a case has been questioned; it has even been argued that the prevalence of liability insurance is itself a reason why the doctrine should now be relegated to the past. ${ }^{19}$ This, I submit, is arguing in a circle; it is saying that an ancient doctrine of domestic relations law may now be abandoned because the bad consequences of its abandonment can be mitigated by holding insurance companies to a contract they did not make. It is interesting to note in this connection that when the New York legislature was recently prevailed upon to make actions of tort for personal injuries available between husband and wife and between parent and child, it enacted simultaneously a statute to the effect that no liability insurance policy should be construed to apply to such actions unless it embodied an explicit provision to that effect. ${ }^{20}$

Once again we see the importance of a clear legal theory, not only of liability insurance, but also of domestic relations law. The whole difficulty of the problem, from either standpoint, revolves around the meaning of the phrase "liability imposed ... by law for damages." That the classic domestic relations law did not permit actions of tort between husband and wife and parent and child is true enough. But it imposed on the husband and father the duty to support his family in all contingencies, and if they suffered personal injuries, either through his own fault or

${ }^{17}$ Joseph W. Madden, Handbook of the Law of Persons and Domestic Relations \$69, 138 (1931).

${ }^{18}$ Luster v. Luster, 299 Mass. 480 , 13 N. E. 2 d 438 (1938).

${ }^{10}$ Willuam L. Prosser, HaNdBook OF the LaW OF TORTS 897-908 (194r).

${ }^{20}$ N. Y. Domestic Relattons Law $\$ 57$ as amended by L. 1937, c. 669; N. Y. Insurance Law $\$ 167(3)$; Fuchs v. London \& Lancashire Indemnity Co. of America, 258 App. Div. 603, I7 N. Y. S. 2d 338 (2d Dep't 1940). 
another's the burden of that duty was, of course, increased. There is no reason why the risk of personal injuries to a family due to the husband and father's carelessness should not be insured against, but that is not a legal problem. It is a problem of drafting the proper policy and determining what the premium ought to be.

Seventh. Another persistent problem which remains, after twenty years, without solution is that raised by the limitation on the underwriter's liability. Suppose the underwriter's liability is limited to $\$ 10,000$ for each person, and that $\$ 20,000$ damages are claimed. The plaintiff offers to settle for \$10,000. The underwriter's normal reaction is to ask the insured to contribute to the settlement. The insured's normal reaction is to insist that the underwriter pay the whole. The underwriter and the insured cannot agree as to what proportion of the \$ro,000 each shall contribute, and

in consequence the settlement is lost. Suppose the action is tried and the plaintift recovers judgment for $\$ 20,000$. May the insured demand that the underwriter pay the whole $\$ 20,000$ on the ground that the underwriter was bound to accept the opportunity to settle for $\$ 10,000$ and to pay the settlement in full?

Twenty-five years ago the Supreme Court of New Hampshire held that the underwriter might be liable if its failure to accept the settlement was the result of negligence. ${ }^{21}$ The New York Court of Appeals took the opposite position, ${ }^{22}$ and the question has been disputed, without any appreciable progress toward solution, ever since. The question is, in fact, insoluble so long as the law permits a situation in which ( $I$ ) the underwriter assumes the burden, and reserves the right of defending any lawsuit which may be brought against the insured driver; (2) the underwriter's liability is limited to an amount smaller than the maximum which the plaintiff may recover from the insured driver; and (3) the underwriter assumes full liability for any judgment which may be rendered against the insured driver up to this minimum amount. If there is any principle of insurance law which can truly be said to be without exception, it is that a valid insurance contract can be distinguished from an invalid wager only by the fact that the insurance contract produces a complete identity of interest between the underwriter and the insured. Where the underwriter is unable or unwilling to carry the whole risk from which the insured wishes to be protected, this identity of interest can be achieved only by the method of "coinsurance," i.e., by a contract under which the underwriter carries a specified share of the insured's risk. Where a specified share of the risk is indeterminate owing to the fact that the risk itself is without limit, the underwriter can be protected only by a "valued policy," i.e., by a contract which sets a definite valuation upon the thing insured.

Valued policies are, of course, impossible in liability insurance so long as the law sets no upper limit on the amounts which may be recovered in actions of tort. In workmen's compensation insurance the risk can be, and is, valued, because compensa-

${ }^{22}$ Douglas v. United States Fidelity \& Casualty Co., 8I N. H. 371, 127 A. 708 (1924).

22 Best Building Co. v. Employers' Liability Assurance Corp., 247 N. Y. 451, I60 N. E. 911 (1928). 
tion is fixed at a percentage of average wages, so that the premium can be computed on the basis of the insured's payroll. The price of the solution of the particular problem now under discussion is legislation fixing a maximum recovery for tortious personal injuries, and the refusal of underwriters to insure for less than this maximum unless the doctrine of coinsurance is applied.

\section{V}

\section{Conclusion}

The idea of insurance is a comprehensive and pervasive one. If it is combined with another idea as comprehensive and pervasive as that of tort, the resulting compound is likely to permeate and color every department of the law. The practice of insurance against tort liability is founded on the combination of these two ideas. The very limited treatment which the subject has hitherto enjoyed in the law curriculum is a measure of that curriculum's resistance to a field of thought which inevitably disrupts the harmony of the accepted scheme. What I have attempted here is to suggest, in the merest outline, the nature of the legal system to which the practice of liability insurance leads. 


\section{-}

